\title{
Two novel species of Neosporidesmium from India
}

\section{J. Pratibha, A. A. Mao \& Ashish Prabhugaonkar*}

Botanical Survey of India, Eastern Regional Centre, Shillong-793003, India

Received 22 March 2018 / Accepted 10 April 2018 / Published 19 April 2018

Pratibha, J., Mao, A.A. \& Prabhugaonkar, A. 2018. Two novel species of Neosporidesmium from India. Mycobiota 8: 9-14. doi: 10.12664/mycobiota.2018.08.02

\begin{abstract}
Two novel species of the asexual ascomycete genus Neosporidesmium are described as $N$. garoense and $N$. khasianum from Garo and Khasi Hills of Meghalaya, India, respectively. Neosporidesmium garoense growing on bamboo litter is distinguished from closely related species by the larger size of synnema and smaller conidia. Neosporidesmium khasianum growing on litter of the tree Wightia speciosissima is distinguished by the size of conidia, the presence of multiple proliferations and the size of synnema.
\end{abstract}

Key words: Ascomycota, asexual morphs, Garo-Khasi hills, India, Meghalaya, Neosporidesmium, new species, synnemata, taxonomy

\section{Introduction}

During routine field explorations in Garo and Khasi hills in Meghalaya, Northeast India, we collected two interesting species of synnematous fungi, one on bamboo litter and another one on dead twigs of the tree Wightia speciosissima. Both fungi resembled the genus Neosporidesmium introduced by Mercado \& Mena in 1988 with $N$. maestrense to accommodate synnematous hyphomycetes characterized by having percurrently proliferating conidiogenous cells forming distinctly swollen subsequent cells and scolecosporous, distoseptate conidia. This genus currently comprises 13 species (Index Fungorum). The two new Indian fungi were found to be distinct upon comparison with all known taxa of Neosporidesmium, hence novel species are described in this paper.

\footnotetext{
*Corresponding author: e-mail: ashishprabhugaonkar@gmail.com
} 


\section{Materials and methods}

Freshly gathered aerial litter samples were taken to the laboratory in zip-lock polythene bags and examined under a stereomicroscope. Synnemata were carefully picked up with a sterile needle, mounted in lactophenol and observed under a light microscope. The holotypes were deposited in the herbarium of the Indian Agricultural Research Institute, New Delhi, India $(\mathrm{HCIO})$. Repeated attempts to get these fungi in culture using single spore isolation methods were not successful.

\section{Taxonomy}

Neosporidesmium garoense J. Pratibha \& Prabhug., sp. nov.

Fig. 1 MycoBank, MB 824922

Colonies on the natural substrate effuse, hairy, dark brown to black. Mycelium partly immersed, partly superficial, composed of dark brown to black, septate, branched, 3-5 $\mu \mathrm{m}$ wide hyphae. Conidiomata macronematous, synnematous. Synnemata solitary, erect, straight, indeterminate, scattered, cylindrical, becoming narrower toward the apex, 700 $1620 \mu \mathrm{m}$ long, 50-65 $\mu \mathrm{m}$ wide at the base, $25-50 \mu \mathrm{m}$ wide in the middle. Conidiophores straight, 4-8 $\mu \mathrm{m}$ wide, septate, unbranched, smooth, brown to dark brown. Conidiogenous cells monoblastic, integrated, terminal, short subcylindrical, doliiform, determinate, smooth, dark brown, $12-20 \times 8-10 \mu \mathrm{m}$, splay out laterally over the whole or at least large portion of the synnemata. Conidia solitary, dry, acrogenous, obclavate, 11-13-distoseptate, smooth, pale brown, truncate at the base, 75-100 $\times 8-11 \mu \mathrm{m}$; apical cell hyaline with a globose, hyaline, 10-12 $\mu \mathrm{m}$ diam. mucilaginous sheath.

Type - INDIA, Meghalaya, Garo hills, Baghmara, on dead culms of Bambusa sp., 29 September 2017, 2512'19.06" N, 90³9'06.02" E, J. Pratibha (holotype, HCIO 52164; isotype BF-99, ASSAM).

Etymology: the epithet refers to Garo hills, Meghalaya, the type locality.

Distribution: so far only known from the type locality.

Habitat and host plant: on a dead culm of Bambusa sp.

Neosporidesmium khasianum Prabhug. \& J. Pratibha, sp. nov.

Fig. 2 MycoBank, MB 824923

Colonies on the natural substrate effuse, hairy, dark brown to black. Mycelium partly immersed, partly superficial, composed of dark brown to black, septate, branched, 3-5 $\mu \mathrm{m}$ wide hyphae. Conidiomata macronematous, synnematous. Synnemata solitary, erect, dark brown to black, cylindrical, slightly narrower towards the apex, 855-2750 $\mu \mathrm{m}$ long, 50-60 $\mu \mathrm{m}$ wide at the base, 40-50 $\mu \mathrm{m}$ wide in the middle. Conidiophores, unbranched, 4-7.5 $\mu \mathrm{m}$ wide, septate, smooth, brown to dark brown. Conidiogenous cells monoblastic, integrated, terminal, doliiform, smooth, brown to dark brown, $15-20 \times 6-10 \mu \mathrm{m}$, with $1-5$ percurrent prolifertations, with constrictions (monilioid), spread along the two-third of the synnemata. Conidia holoblastic, solitary, dry, acrogenous, obclavate, 10-12-distoseptate, smooth, brown, apex obtuse, paler, base truncate, darkened, 103-135 × 10-18 $\mu \mathrm{m}$. 

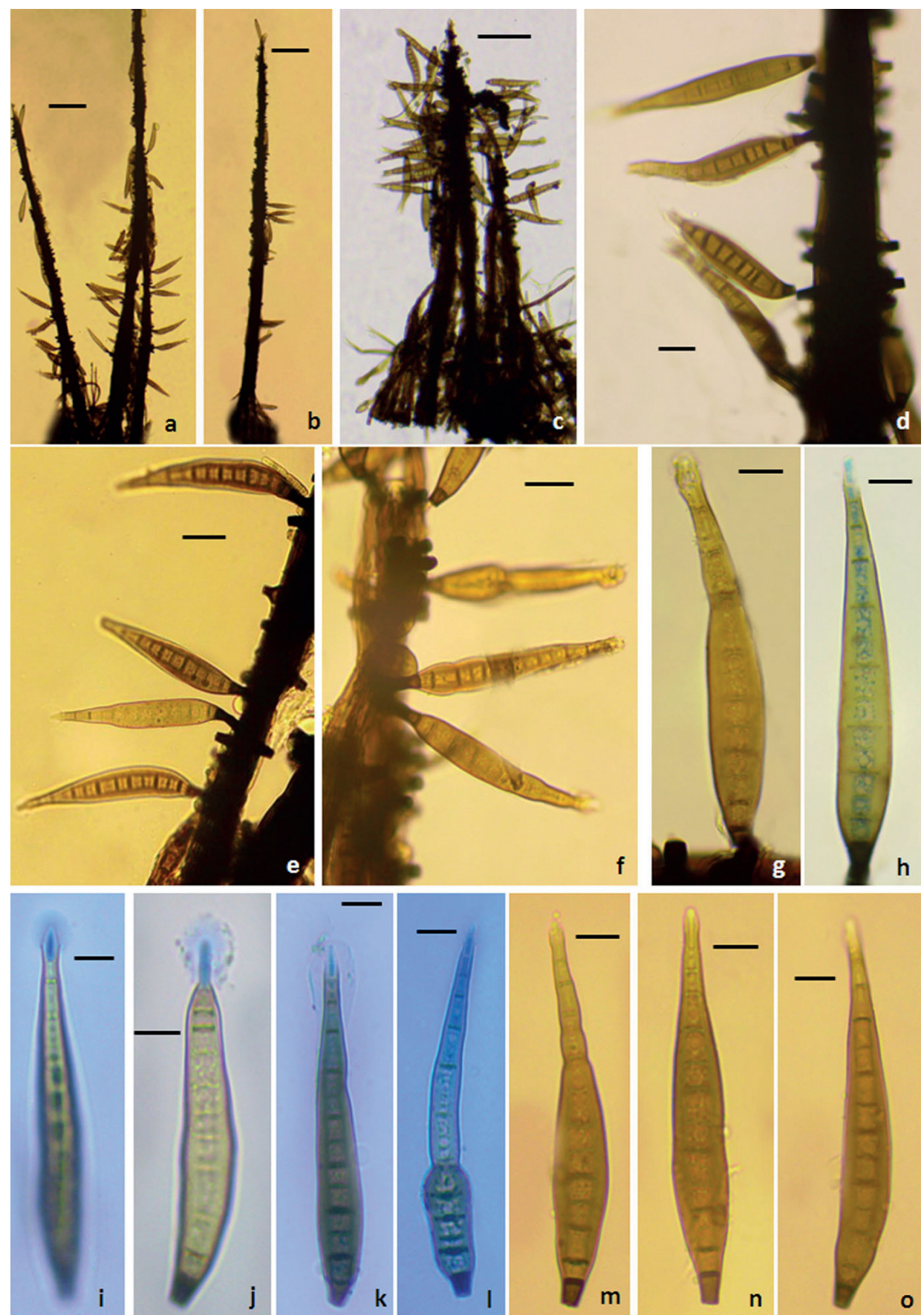

Fig. 1. Neosporidesmium garoense: $\mathbf{a}-\mathbf{c}-$ synnema, $\mathbf{d}-\mathbf{h}-$ conidiogeous cells and conidia, $\mathbf{i}-\mathbf{o}$ - conidia. Scale bars: $\mathrm{a}-\mathrm{c}=100 \mu \mathrm{m}, \mathrm{d}-\mathrm{f}=20 \mu \mathrm{m}, \mathrm{g}-\mathrm{o}=10 \mu \mathrm{m}$ 
Type - INDIA, Meghalaya, East Khasi Hills, forest patch Near Puriang village, on

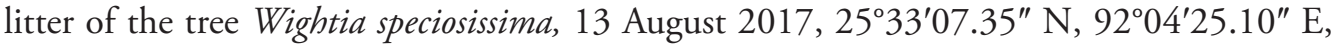
1280 m, A. Prabhugaonkar (holotype, HCIO 52162; isotype AVP-154, ASSAM).

Etymology: the epithet refers to Khasi hills, Meghalaya, the type locality.

Distribution: so far only known from the type locality.

Habitat and host plant: hanging twig litter of Wightia speciosissima.

\section{Discussion}

Two recent papers on the genus Neosporidesmium (Prasher \& Verma 2015; Mel'nik et al. 2016) provide detail reviews of the genus and keys to the species. These taxonomic treatments paved the way for further studies on this comparatively recently discovered genus. The new species $N$. garoense is similar to $N$. diaoluoshanense (Li et al. 2015), the only other species with conidia provided with a spherical apical mucilagenous sheath, but differs in having much longer synnema and smaller conidia. In $N$. diaoluoshanense the synnemata are up to $605 \mu \mathrm{m}$ long and the conidia are 105-135 $\mu \mathrm{m}$ long, whereas in $N$. garoense synnemata are 700-1620 $\mu \mathrm{m}$ long and the conidia are 75-100 $\mu \mathrm{m}$ long.

$N$. khasianum is rather similar to N. maestrense, the type species of Neosporidesmium (Mercado \& Mena 1988), with synnemata more than $2 \mathrm{~mm}$ high and with multiple percurrently proliferating conidiogenous cells, however, it differs in the size of the conidia and the size and width of synnemata. In $N$. maestrense, conidia are 55-100 $\mu \mathrm{m}$ long and synnemata are up to $2500 \mu \mathrm{m}$ long and 60-250 $\mu \mathrm{m}$ wide, whereas in $N$. khasianum the conidia are 103-135 $\mu \mathrm{m}$ long and the synnemata are up to $2750 \mu \mathrm{m}$ long and only 40-60 $\mu \mathrm{m}$ wide.

Species of the genus Neosporidesmium are as far as is known saprobic. However, little is known about substrate preferences of the particular species. Most species are only known from a single or few collections. $N$. garoense is the first species in Neosporidesmium inhabiting bamboo litter while $N$. khasianum occurs on litter of a new tree host, Wightia speciosissima.

Attempts to cultivate the two new Indian species failed and impeded the generation of molecular phylogenetic data as in most species of Neosporidesmium. The only available sequence of a Neosporidesmium species (Shenoy et al. 2006) places this genus in Dothideomycetes, but this placement is not representative for this genus as its type species, $N$. maestrense, has not yet been sequenced. The generation of cultures of Neosporidesmium species, including the type species of this genus, and results of sequence analyses is the most important challenge for the future in order to elucidate the phylogenetic affinity of the genus and its species.

Acknowledgements. The authors are thankful to the Director, Botanical Survey of India, Kolkata for facilities. Herbarium Cryptogamae Indiae Orientalis (HCIO), IARI, New Delhi is thanked for depositing the type specimens. 


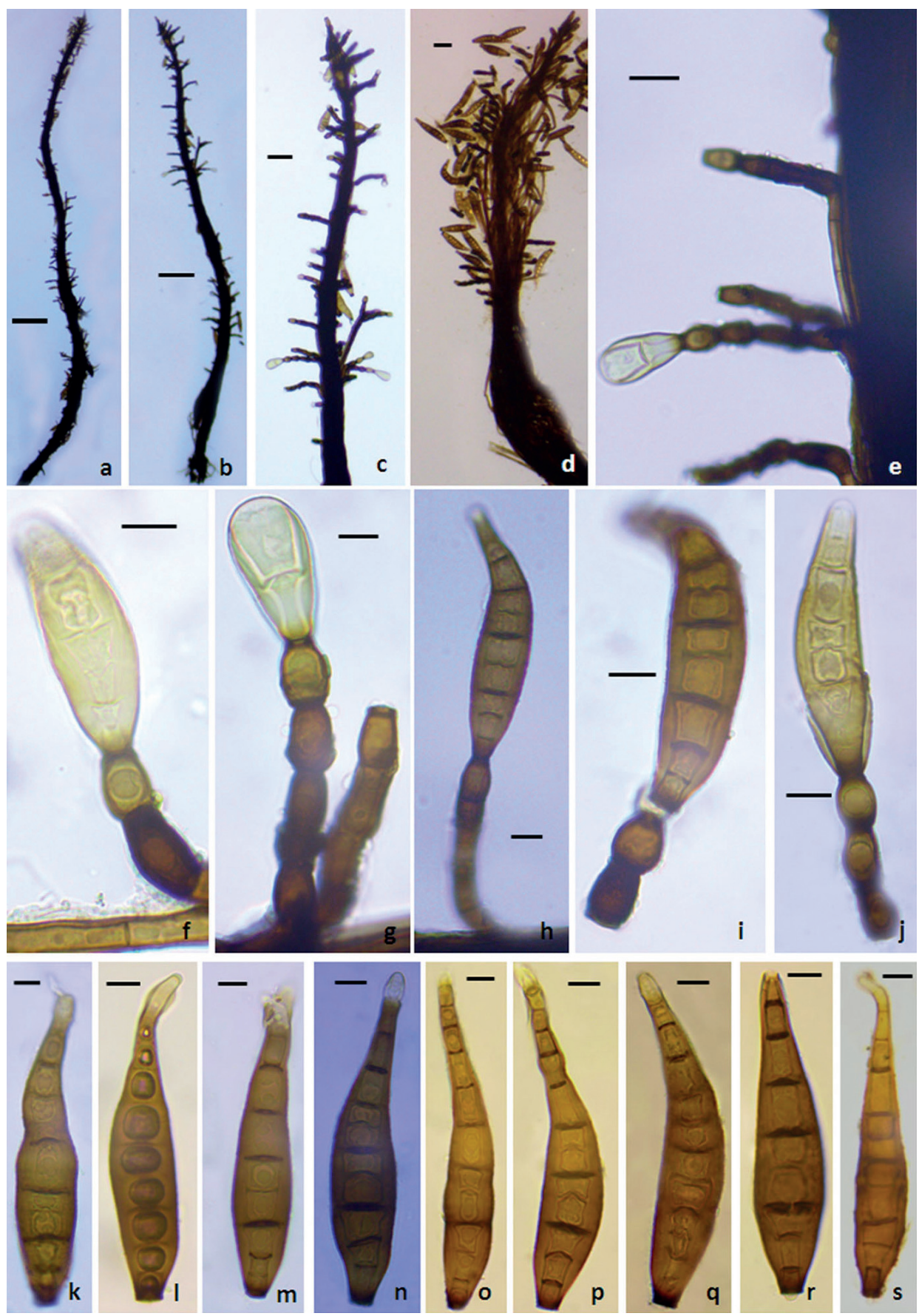

Fig. 2. Neosporidesmium khasianum: $\mathbf{a}-\mathbf{d}-$ synnema, $\mathbf{e}-\mathbf{j}-$ conidiogeous cells and conidia, $\mathrm{k}-\mathrm{s}-$ conidia. Scale bars: $\mathrm{a}, \mathrm{b}=200 \mu \mathrm{m}, \mathrm{c}, \mathrm{d}=50 \mu \mathrm{m}, \mathrm{e}=20 \mu \mathrm{m}, \mathrm{f}-\mathrm{s}=10 \mu \mathrm{m}$ 


\section{References}

Li, X.Y., Liu, S.Y. \& Zhang, X.G. 2015. A new species of Neosporidesmium from Hainan, China. Mycotaxon 130: 307-310. https://doi.org/10.5248/130.307

Mel'nik, V.A., Popov, E.S. \& Braun, U. 2016. Neosporidesmium subramanianii sp. nov. from Vietnam. Mycosphere 7: 148-153. https://doi.org/10.5943/mycosphere/7/2/6

Mercado, S.A. \& Mena, P.J. 1988. Nuevos o raros hifomicetes de Cuba. - Acta Botanica Cubana 59: 1- 6.

Prasher, I.B. \& Verma R.K. 2015. Neosporidesmium appendiculatus sp. nov. from North-Western India. Mycological Progress 14: 1-6. https://doi.org/10.1007/s11557-015-1112-5

Shenoy, B.D., Jeewon, R., Wu, W.P., Bhat, D.J. \& Hyde, K.D. 2006. Ribosomal and RPB2 sequence analyses suggest that Sporidesmium and morphologically similar genera are polyphyletic. - Mycological Research 110: 916-929. https://doi.org/10.1016/j.mycres.2006.06.004 